\title{
A Novel Experimental Method for the Study of Intestinal Paralysis due to Endotoxicosis
}

\author{
Norifumi Ninomiya ${ }^{1}$, Kayo Nemoto ${ }^{2}$, Tadao Okamura ${ }^{2}$ \\ Hidenori Suzuki ${ }^{2}$, and Yasuhiro Yamamoto ${ }^{1}$
}

\begin{abstract}
Lipopolysaccharide (LPS) is thought to be the causal agent of paralytic ileus in sepsis. We have reported that contraction of taenia caecum isolated from guinea pigs is suppressed by LPS. In the present study, we tried to create a new experimental method for the study of intestinal paralysis induced by LPS with continuously recorded changes in the movement of taenia caecum of conscious guinea pigs. Laparotomy was performed under pentobarbital anesthesia in guinea pigs, and a microforce transducer was sutured on taenia caecum. After operation, the guinea pigs were allowed to eat and drink freely. Four days later, LPS (E. coli, O111: B4) was injected into the abdominal cavity, and the movement of taenia caecum was recorded. Changes in body temperature after the administration of LPS were measured successively. Intestinal contraction movements in conscious guinea pigs were recorded in a stable manner for many hours. The characteristic relaxing action of taenia caecum was that it peaked between 2 and 4 hours after administration of LPS and that it was dependent on the LPS-dose. Body temperature changed in good correlation to the tension of taenia caecum. The above results suggest that the novel method, monitoring the intestinal movement of conscious guinea pigs, is a useful experimental model for the study of intestinal paralysis due to endotoxicosis.
\end{abstract}

(JJAAM $2003 ; 14: 241-50)$

Key Words: sepsis, ileus, lipopolysaccharide, smooth muscle, guinea pig

Received for publication on June 14, 2002 (02-058)

\section{INTRODUCTION}

Lipopolysaccharide (LPS) has been known to play a key role in pathophysiology of sepsis caused by Gramnegative bacteria. Treatment and prevention of LPS-induced physiological dysfunctions of multiple organs is one of the important themes of emergency medicine. The serious problem of paralytic ileus often encountered in septic patients is that intestinal bacteria proliferate due to decreased intestinal movement ${ }^{1,2)}$, and at the same time, bacterial translocation occurs easily ${ }^{3,4)}$, resulting in exacerbation of sepsis. To treat paralytic ileus at the early stage improves prognosis and may lead to increases in the survival rate. Current treatment of early return to per-intesti-

\footnotetext{
Correspondence:

${ }^{1}$ Department of Emergency and Critical Care Medicine, Nippon Medical School

${ }^{2}$ Department of Pharmacology, Nippon Medical School

Sendagi 1-1-5, Bunkyo, Tokyo 113-8603
}

nal nutrition aims at improving intestinal movement. It is ideal to elucidate the mechanism of paralytic ileus, making it possible to treat the condition at its cause. In the present study, paying attention to paralytic ileus in sepsis, we conducted experiments using guinea pig intestines in order to elucidate the mechanism of action.

In the previous report, we have examined an effect of LPS in vitro on the intestine isolated from guinea pigs, the experimental animals known to be highly sensitive to LPS ${ }^{5)}$. We have shown that direct application of LPS does not show any immediate effect on the isolated intestine preparation but the contractile activity of the intestine isolated after 20 hours of intraperitoneal injection of LPS is clearly suppressed. These results have strongly suggested that LPS induces some biological responses during 20 hours after administration, which indirectly results in suppression of the contractile activity of the intestine. In other words, the result demonstrated that an in vivo experimental system is needed to elucidate actions of LPS on the intestine. Therefore, in the present study, in vivo intestinal 
movement was monitored to evaluate effects of LPS doses on intestinal movement and observe successively manifestation of action of LPS.

Monitoring the intestinal movement in small animals has been accomplished for the rat stomach ${ }^{6}$. However, placement of an electric transmitter in the abdominal cavity as in the reported method causes compression and invasion against visceral organs, which makes it difficult to analyze experimental results precisely. To overcome this problem, we utilized the taenia caecum of guinea pigs and installed the electric transmitter in the region with less compressive and invasive effect on abdominal visceral organs. The taenia caecum is composed of longitudinal muscle bundles of the intestine. With these means, we successfully monitored the intestinal movement stably for many hours and examined effects of LPS on the intestinal activity in vivo.

Establishment of continuous recording method for the intestinal movement in conscious and unrestrained guinea pigs strongly suggests that our method could be generally useful as an experimental model for paralytic ileus, which would make it possible to elucidate pathophysiology of the disease.

\section{MATERIALS AND METHODS}

\section{1) Recording of longitudinal muscle movement of the taenia caecum}

Male Hartley guinea pigs (body weight, $350-450 \mathrm{~g}$ ) were used for experiments under the approval of the Animal Experimental Ethical Review Committee of Nippon Medical School (No.13-67). Guinea pigs received laparotomy under anesthesia with pentobarbital sodium (30 $\mathrm{mg} / \mathrm{kg}$ body weight, intraperitoneal injection). A force transducer $(3 \mathrm{~mm} \times 5 \mathrm{~mm}, \mathrm{~F}-041 \mathrm{~S}$, Star Medical Inc., Japan) was sutured on the taenia caecum. A cylindrical electric transmitter $(\phi 15 \mathrm{~mm} \times 35 \mathrm{~mm}$, IMT-10T, Star Medical Inc.) connected to the transducer via a cable was embedded subcutaneously in the dorsal region of the animals and fixed by surgical suture.

Signals from the transmitter were obtained by a receiver (IMT-10RA, Star Medical Inc.) set under breeding cages, from which output signals were transmitted to a personal computer to record changes in tension of the longitudinal muscle continuously. The animals after operation were allowed to eat and drink freely. LPS (E. coli, serotype O111:B4) at given doses was intraperitoneally injected to the animals after four to five days of operation, and the longitudinal muscle movement of the taenia caecum was continuously recorded. Three or four animals were used for each dose of LPS.

Chronological changes in the longitudinal muscle movement were evaluated by using motor indices representing changes in tension and in contractility of the muscle. The motor indices used for evaluating effects of LPS on the taenia caecum muscle were tension and contractility, the latter of which consisted of cycles of contraction wave (cycles/10 min), mean amplitude of contraction wave (g/ $10 \mathrm{~min})$ and area under contraction wave $(\mathrm{g} \cdot \mathrm{min} / 10$ $\min )$.

\section{2) Measurement of body temperature}

Depilation was performed between the right and left blade bones on the back of the animals, and a plate-type thermosensor (PTP-50, Unique Medical Co., Ltd., Japan) was tightly fixed on the skin. Skin temperature was recorded continuously on a temperature monitor (PTC-301, Unique Medical Co., Ltd.).

\section{3) Reagents}

Lipopolysaccharide (LPS) from E. coli serotype O111: B4 was obtained from Sigma Chemical Co. (St. Louis, USA), and pentobarbital sodium was from Schering Praw Co. (New Jersey, USA).

LPS was diluted in sterile saline.

\section{4) Statistical analysis}

All experimental results were shown as mean \pm SEM. Statistical differences were determined by repeated measure analysis of variance (ANOVA). Paired $t$-test was used to evaluate differences between two groups. P-values less than 0.05 were considered statistically significant.

\section{RESULTS}

\section{Typical recording of muscle tension induced by in- jection of LPS}

Guinea pigs receiving operation for suturing a microforce transducer moved, ate and drank freely after arousal from anesthesia. The amount of defecation during the breeding period until LPS administration was similar to that before the operation. The contractile activity and tension of the longitudinal muscle of the taenia caecum increased gradually and reached a stable state, in which rhythmic contraction was observed, within several hours after arousal. Circadian variation in the contractility was not found in prior to LPS administration; the intestine showed rhythmic contraction through a diurnal cycle. 
Fig. 1 shows recording of changes in contraction of the longitudinal muscle of the taenia caecum. Examples of the intestinal contractions are exhibited with increasing doses of LPS; lower panels show the effect of higher doses of LPS. The horizontal axis indicates the time (hr) after administration of LPS, and the vertical axis, tension ( $\mathrm{g}$ ) of the longitudinal muscle of the taenia caecum. At any doses, tension declined and reached the lowest peak at three to four hours after administration of LPS. Then tension gradually recovered in a dose-dependent manner. The animals receiving 3 and $10 \mathrm{mg} / \mathrm{kg}$ of LPS in which intestinal tension was not recovered within 24 hours all died.

\section{Typical recording of contractile waves induced by injection of LPS}

Typical examples of contractile waves of the taenia caecum in the guinea pig receiving intraperitoneal injection of LPS $(10 \mathrm{mg} / \mathrm{kg})$ are shown in Fig. 2. Contractions were recorded for ten minutes at 1, 3, 5, 9 and 11 hours after LPS administration. The vertical axis shows tension $(\mathrm{g})$, and the horizontal axis, time ( $\mathrm{min})$. The motor indices described in MATERIALS AND METHODS were used for analysis of contractility. Movement of the longitudinal muscle of the taenia caecum was characterized by that muscle tension was sustained at a constant level and that the sustained tension formed slow rhythmic waves repetitively (contractile waves). At three hours after administration of LPS, both the muscle tension and the amplitude of the contractile waves were decreased compared to those observed at the beginning of the experiment.

\section{Effects of LPS on the contractile activity of the lon- gitudinal muscle of the taenia caecum}

Fig. 3 shows effects of LPS intraperitoneally injected into guinea pigs on the contractile activity of the longitudinal muscle. Cycles of contractile wave (Fig. 3A), amplitude of contractile wave (Fig. 3B) and area under contractile wave (Fig. 3C) were measured for ten minutes at one-hour interval, and the mean values from three animals are plotted. The vertical axis indicates the above values in percentage of the corresponding values obtained for ten minutes before administration of LPS. The horizontal axis shows time (hr) after the administration. There was no statistically significant difference due to administration of LPS in any of the motor indices representing contractile activity of the muscle. In addition, no significant dose dependency was observed.

\section{Effects of LPS on tension of the longitudinal muscle of the taenia caecum}

Effects of LPS intraperitoneally injected into guinea pigs on the muscle tension are shown in Fig. 4, in which changes in the muscle tension measured at one- hour interval are represented. The vertical axis indicates the tension in percentage of that recorded for ten minutes before administration of LPS. The muscle tension in the guinea pig euthanized with pentobarbital is shown as $0 \mathrm{~g}(0 \%)$.

Tension of the longitudinal muscle declined immediately after administration of LPS, and statistically significant decrease was found at three hours after administration at any dose examined. Moreover, the maximum decrease in the muscle tension was observed at three to four hours after administration in all the treated groups receiving $0.3,1,3$ and $10 \mathrm{mg} / \mathrm{kg}$ of LPS. After reaching the maximum decrease, tension gradually recovered and returned to the normal level within eight hours in the group with $0.3 \mathrm{mg} / \mathrm{kg}$ of LPS. On the other hand, one fourth of the animals receiving $1 \mathrm{mg} / \mathrm{kg}$ of LPS died, in which the intestinal tension did not recover completely. Furthermore, the muscle tension was sustained low and all animals died within 20 hours in the $10 \mathrm{mg} / \mathrm{kg}$ - group. Mortality after 24 hours of administration of LPS at each dose is demonstrated in Fig. 5 Each group included three to four animals.

\section{Effects of LPS on body temperature in guinea pigs}

When injecting $0.3 \mathrm{mg} / \mathrm{kg}$ of LPS dissolved in sterile saline intraperitoneally into guinea pigs, tension of the longitudinal muscle of the taenia caecum decreased with time as indicated with open circles in Fig. 6, in which the left vertical axis shows tension ( $\mathrm{g}$ ), and the horizontal axis, time $(\mathrm{hr})$. Changes in body temperature (closed circles) are plotted on the right vertical axis $\left({ }^{\circ} \mathrm{C}\right)$. Body temperature transiently increased for approximately one hour after LPS administration, and then began to decrease, as did the muscle tension. Time courses for decrease in the intestinal muscle tension correlated well with that for decrease in body temperature.

\section{DISCUSSION}

In the present study, an in vivo experimental method was developed for observation of changes in colonic movement following administration of endotoxin. A subminiature force-transducer was sutured to the longitudinal muscle of the colon of guinea pigs, making it possible to record steadily for many hours the movement of the lon- 


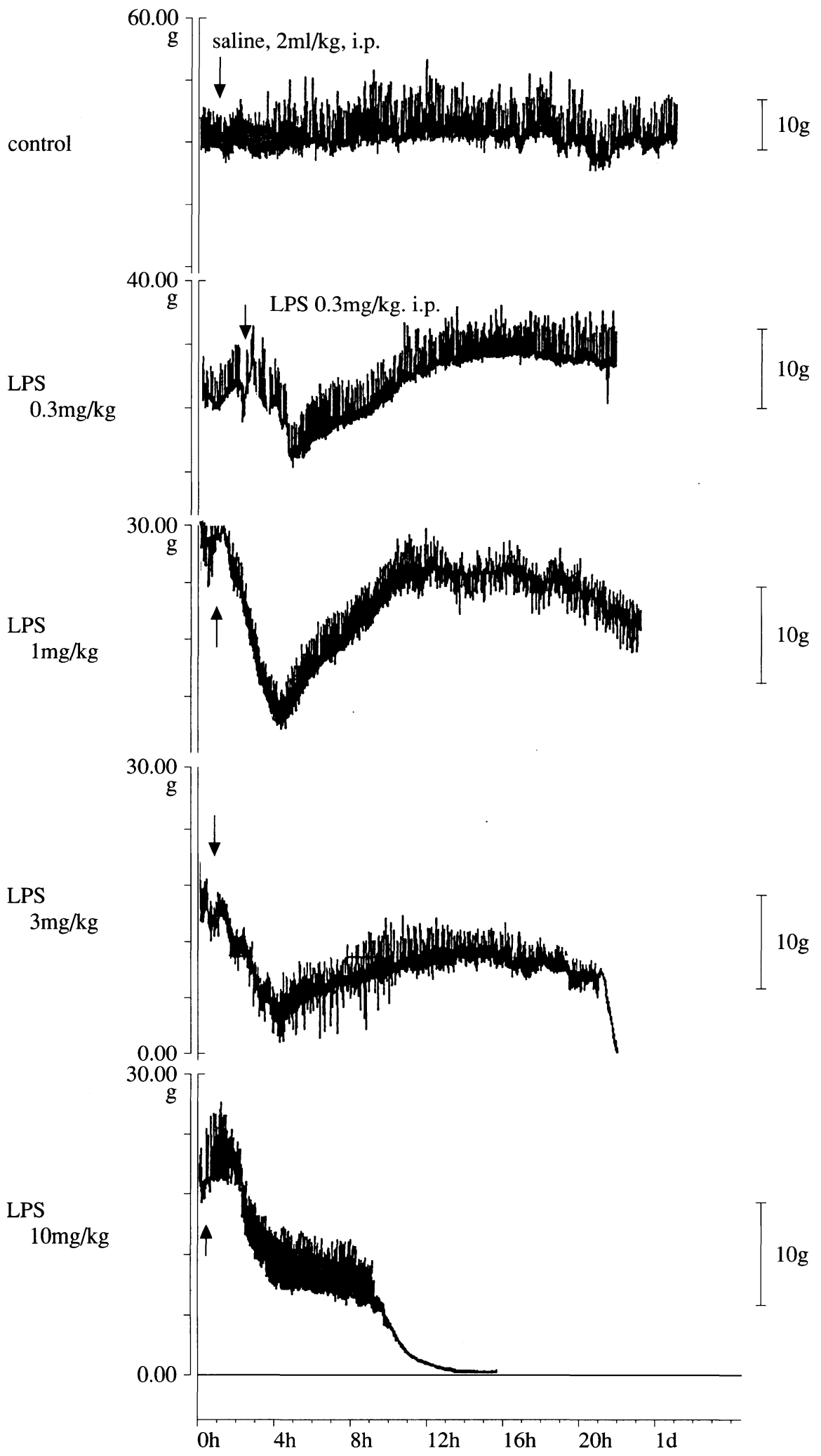

Fig. 1. Typical recording of muscle tension induced by injection of LPS.

Individual guinea pigs were injected intraperitoneally with LPS $0.3,1,3$ and $10 \mathrm{mg} / \mathrm{kg}$ at the time point of arrows. Vertical bar shows the muscle tension $(\mathrm{g})$ and horizontal bar shows time (hr). 

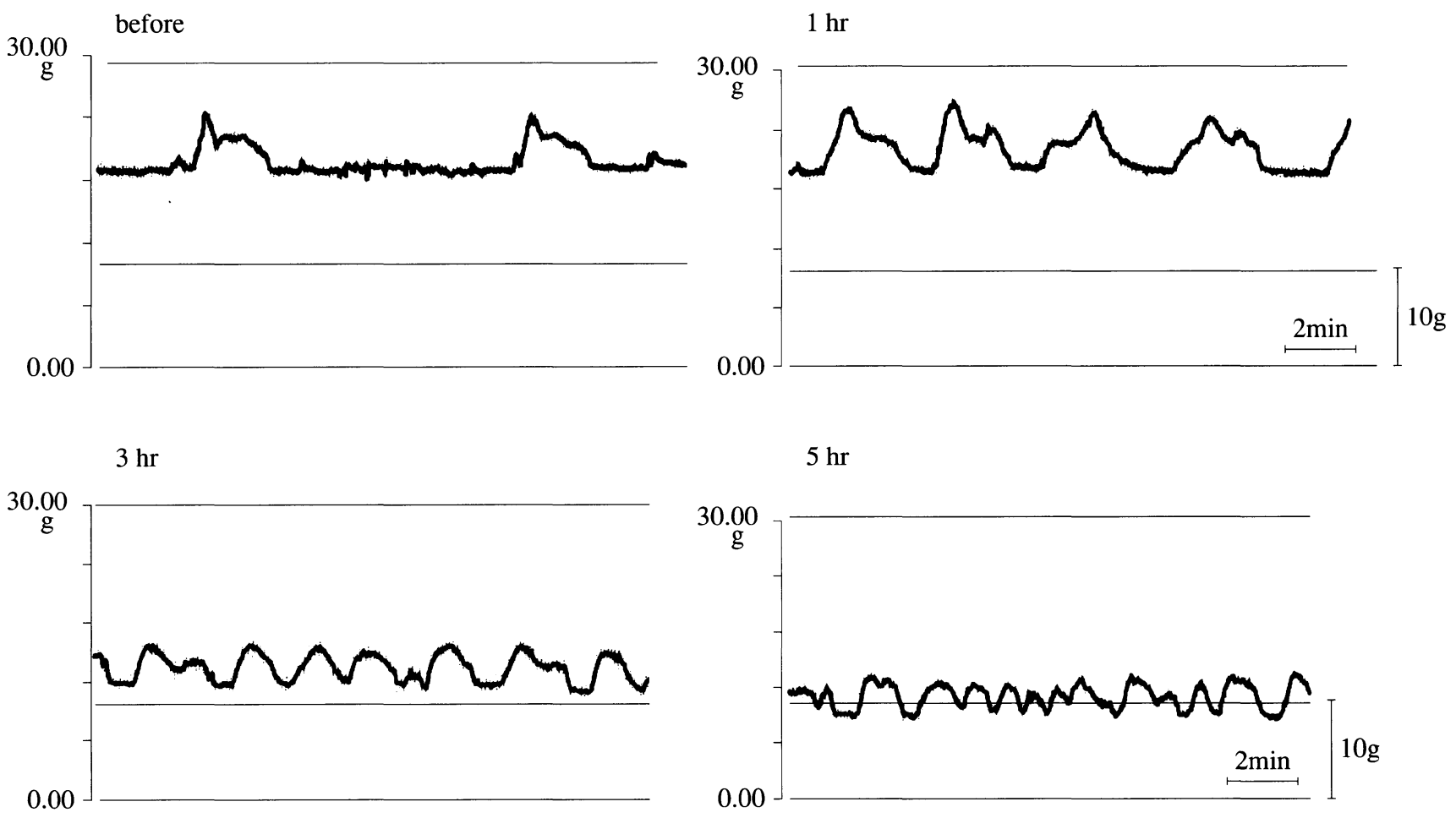

$9 \mathrm{hr}$

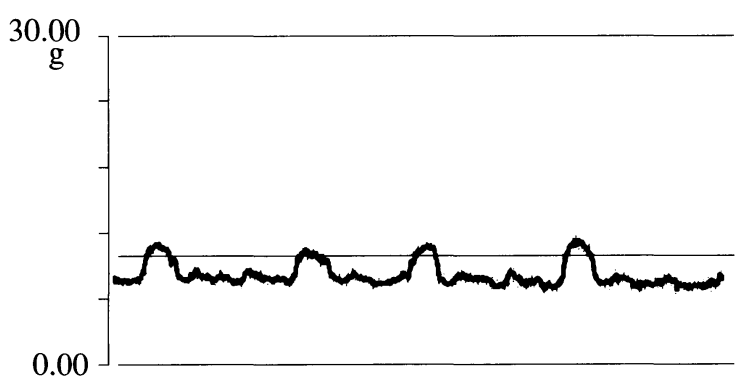

$11 \mathrm{hr}$

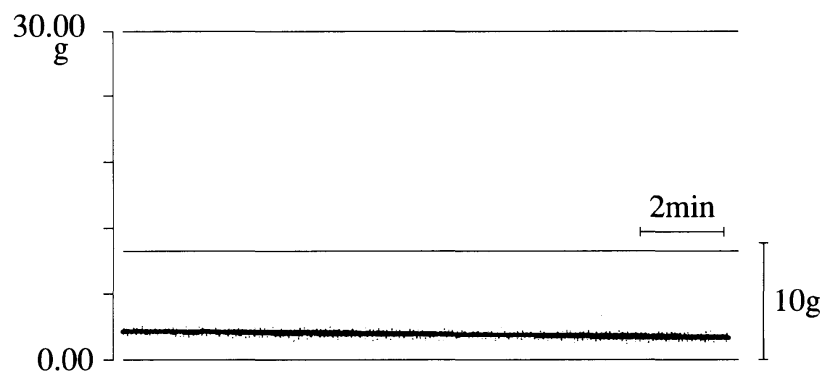

Fig. 2. Typical recording of contractile waves induced by injection of LPS.

Each record shows the contractile wave at $1,3,5,9$ and $11 \mathrm{hr}$ after injection of LPS $10 \mathrm{mg} / \mathrm{kg}$ intraperitoneally. Each panel was obtained from recordings for $10 \mathrm{~min}$ at each point.

gitudinal muscle of the colon, while guinea pigs were conscious and unrestricted. By employing the new method, decreases in intestinal tension were detected following administration of endotoxin.

Although motor paralysis of the small intestine seems to be the principal problem in paralytic ileus, movement of the small intestine is produced by complex contractions of the circular muscle, longitudinal muscle and lamina muscularis mucosae as well as complicated nervous controls by intrinsic nervous plexus and extraneous nerves. Consequently, the bands of guinea pig colon comprising thick longitudinal muscular tunics were chosen for the material of the present study, avoiding the small intestine, as smooth muscle contraction can be simplified in movement of the bands of the colon.

The taenia caecum is a smooth muscle tissue, in which string bundles of smooth muscle cells run longitudinally, and thus can develop a large tension. In addition, the taenia caecum is located along with the abdominal wall subjacent to the midline. These histological, functional and anatomical characteristics of the taenia caecum encouraged us to mount the force transducer on this region with minimal surgical injury and bleeding. Moreover, we placed an electric transmitter of minimal size subcutaneously on the dorsal region of the animals instead in the abdominal cavity, that made it possible to reduce invasion such as 
$\mathbf{A}$

$\mathbf{A}$
0
0
0
0
0
0
0
0
0
0
0
0
0
0
0
0

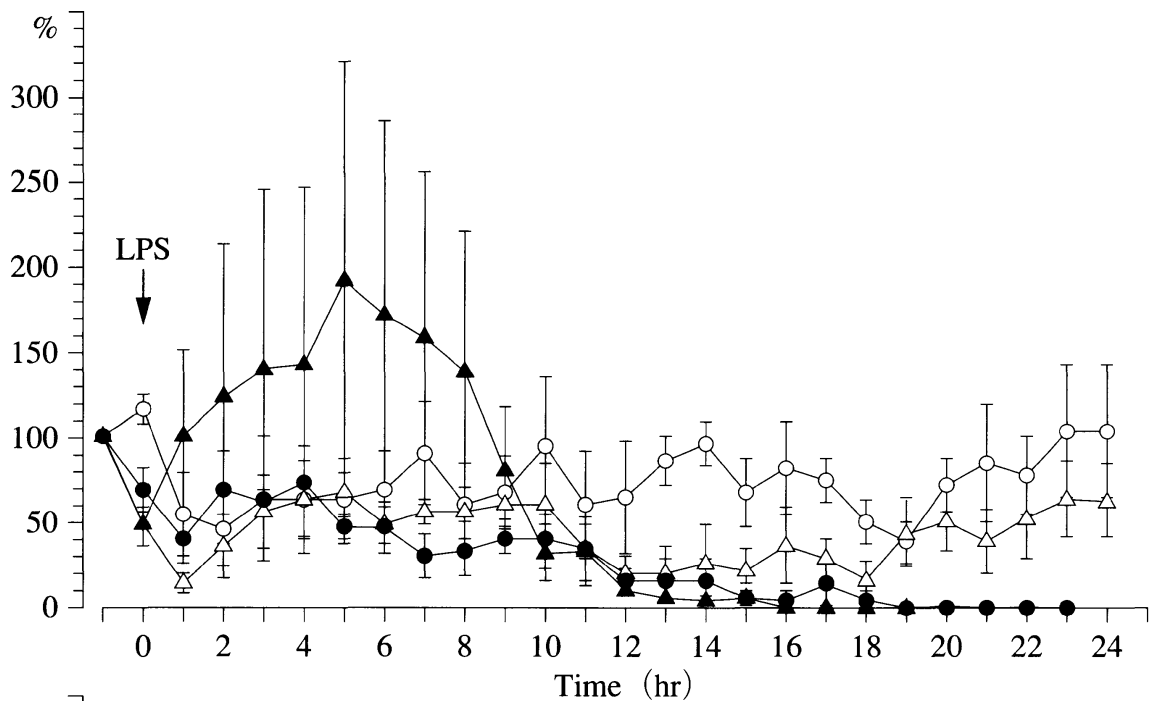

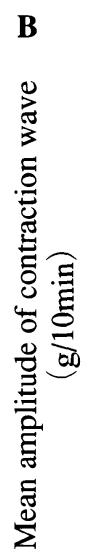

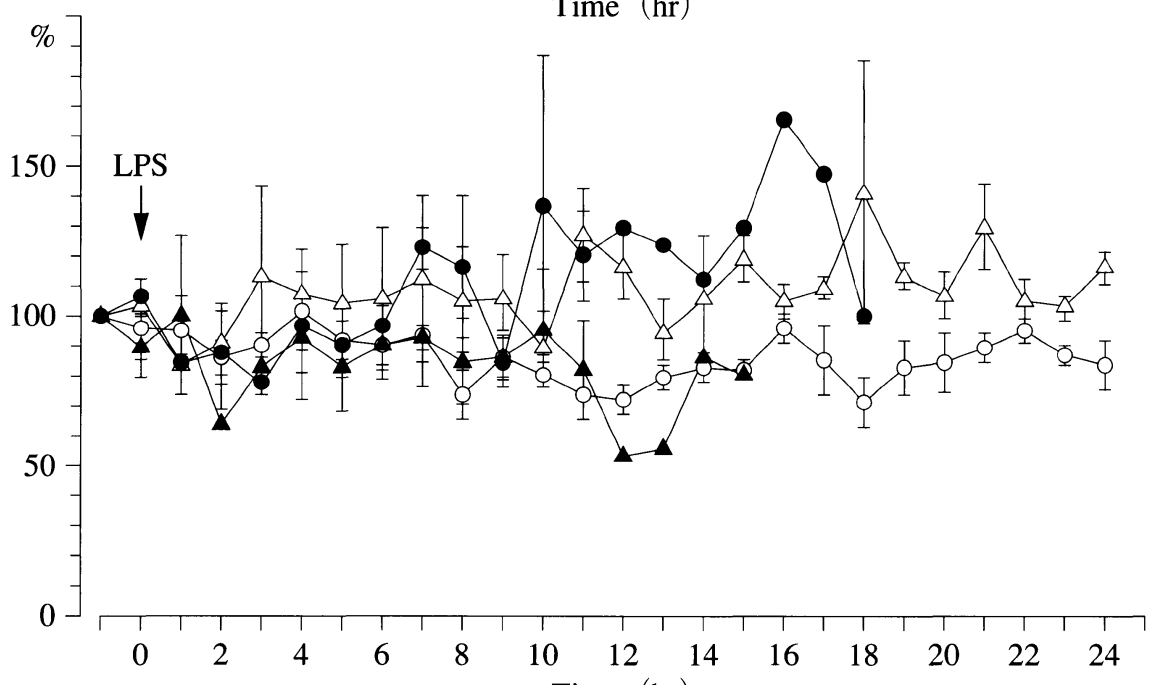

C

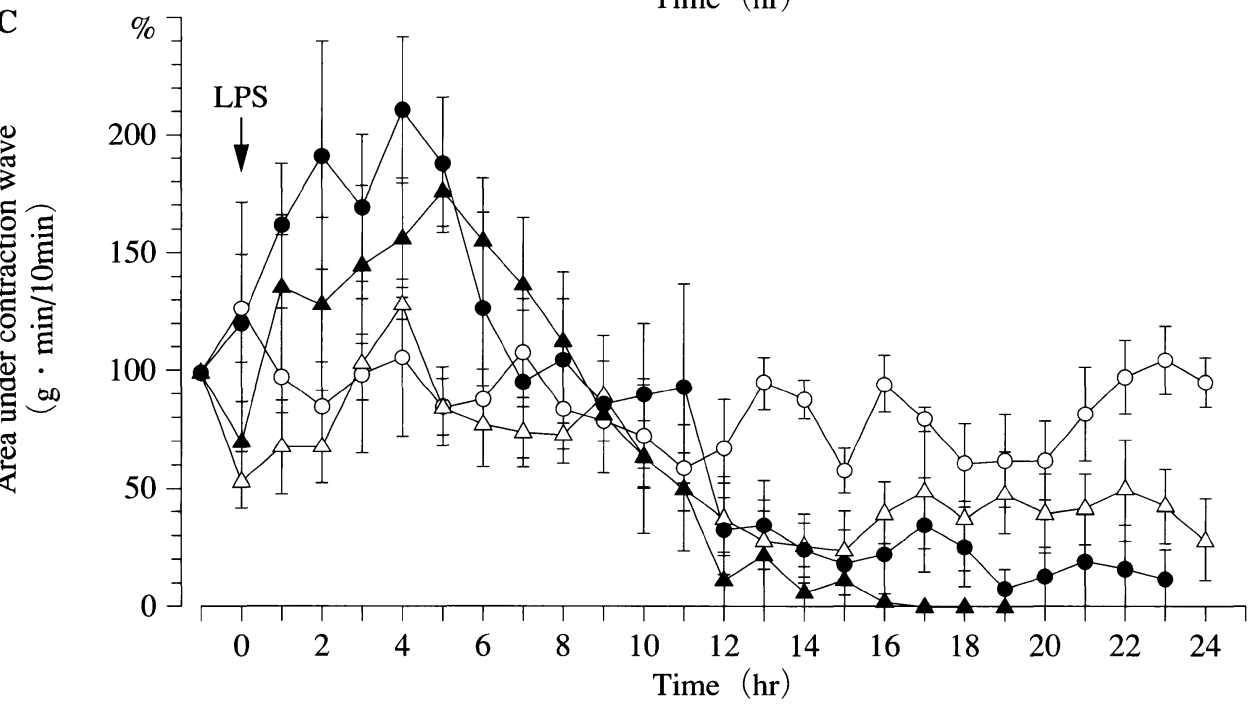

Fig. 3. Effects of LPS on the contractile activity of guinea pig taenia caecum.

The contractile activity was evaluated with the motor indices (see text), cycle of contraction wave (A), mean amplitude of contraction wave (B) and area under contractile wave (C). Individual guinea pigs were injected with LPS $0.3 \mathrm{mg} / \mathrm{kg}(\bigcirc), 1 \mathrm{mg} / \mathrm{kg}(\triangle), 3 \mathrm{mg} / \mathrm{kg}(\bigcirc)$ or $10 \mathrm{mg} / \mathrm{kg}(\boldsymbol{\Delta})$ intraperitoneally at the 0 time point. Points show the mean \pm SEM $(n=3-4)$. 


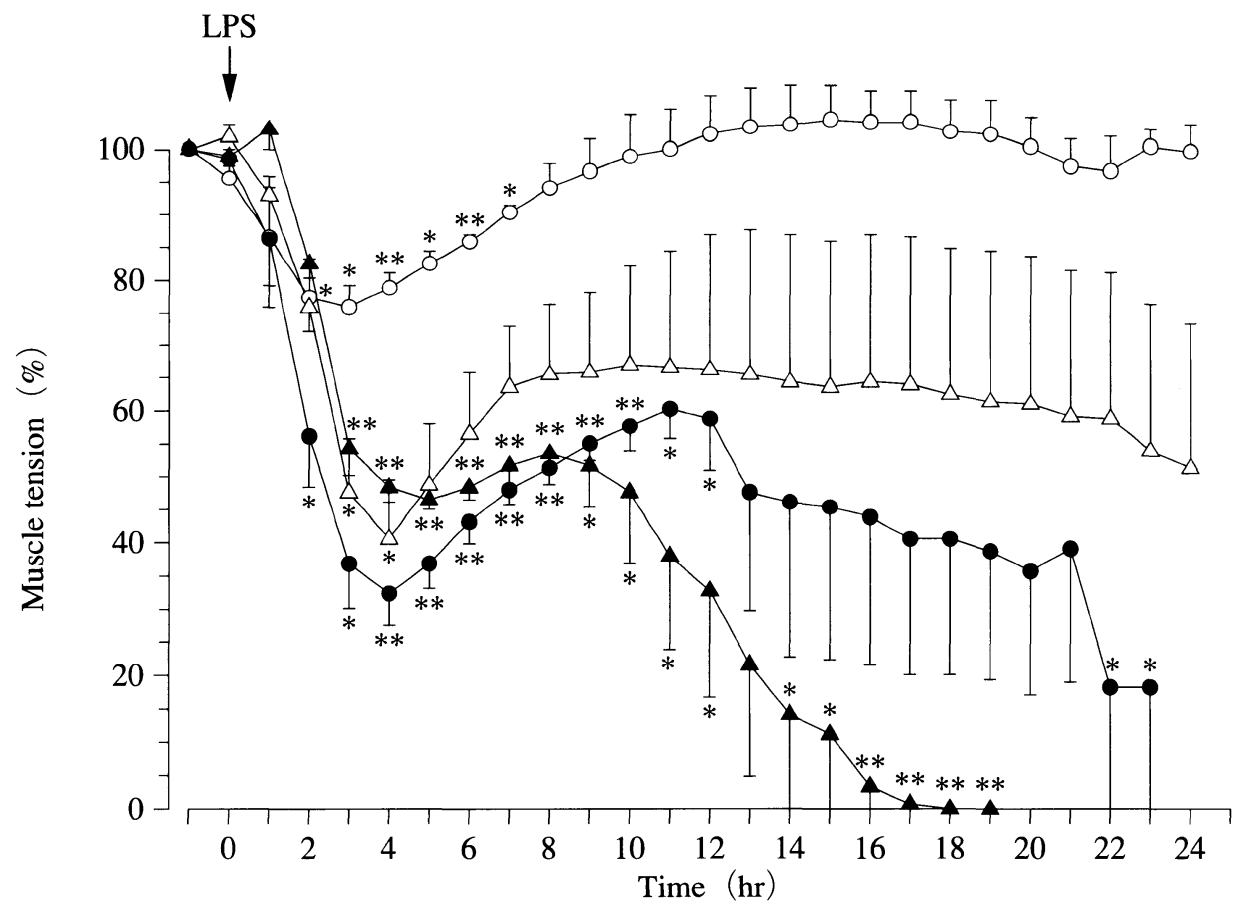

Fig. 4. Effects of LPS on muscle tension of guinea pig taenia caecum. Individual guinea pigs were injected with LPS $0.3 \mathrm{mg} / \mathrm{kg}(\bigcirc), 1 \mathrm{mg} / \mathrm{kg}(\triangle), 3 \mathrm{mg} / \mathrm{kg}(\bigcirc)$ or $10 \mathrm{mg} / \mathrm{kg}(\boldsymbol{\Delta})$ intraperitoneally at the 0 time point.

${ }^{*} \mathrm{p}<0.05,{ }^{*} \mathrm{p}<0.01$ compared with the corresponding point at the $10 \mathrm{~min}$ before injection of LPS. Points show the mean \pm SEM $(n=3-4)$.

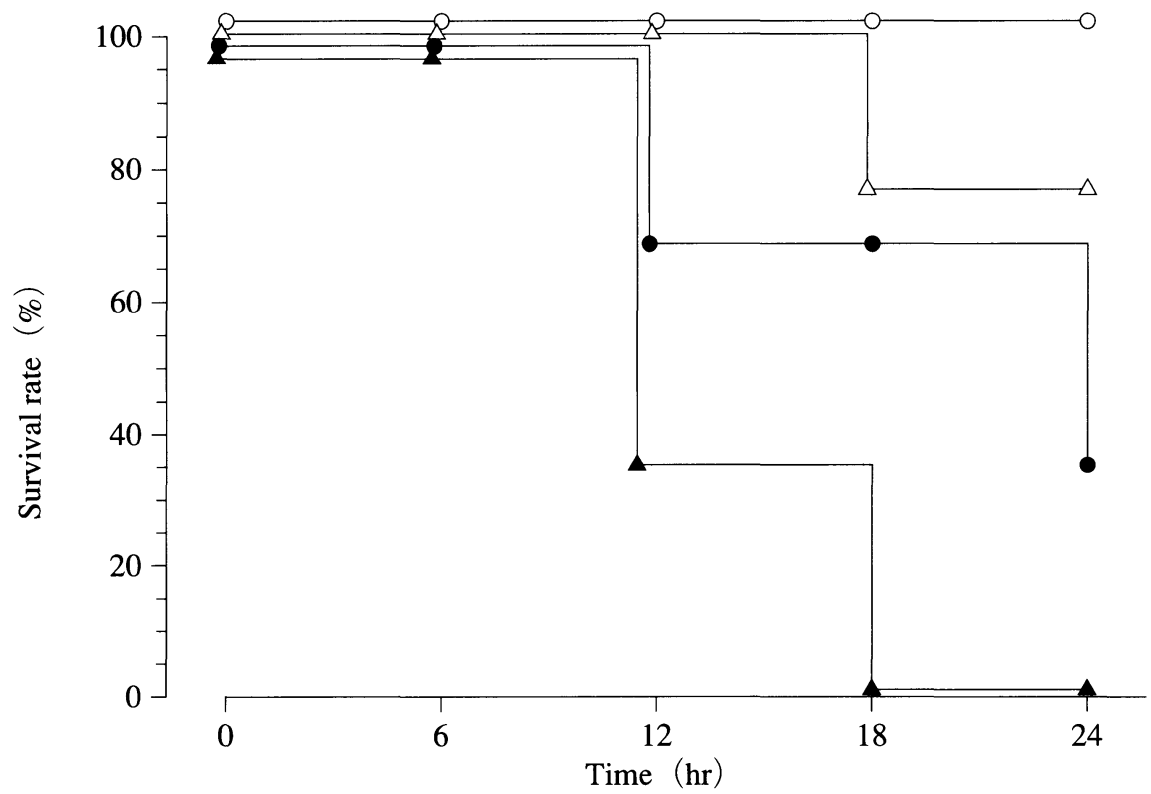

Fig. 5. Mortality of guinea pigs injected with LPS.

Individual guinea pigs were injected with LPS $0.3 \mathrm{mg} / \mathrm{kg}(\bigcirc), 1 \mathrm{mg} / \mathrm{kg}(\triangle), 3 \mathrm{mg} / \mathrm{kg}$ or $10 \mathrm{mg} / \mathrm{kg}(\boldsymbol{\Delta})$ intraperitoneally $(\mathrm{n}=3-4$ per group). Mortality was monitored at 6 , $12,18,24 \mathrm{hr}$ after the injection. 


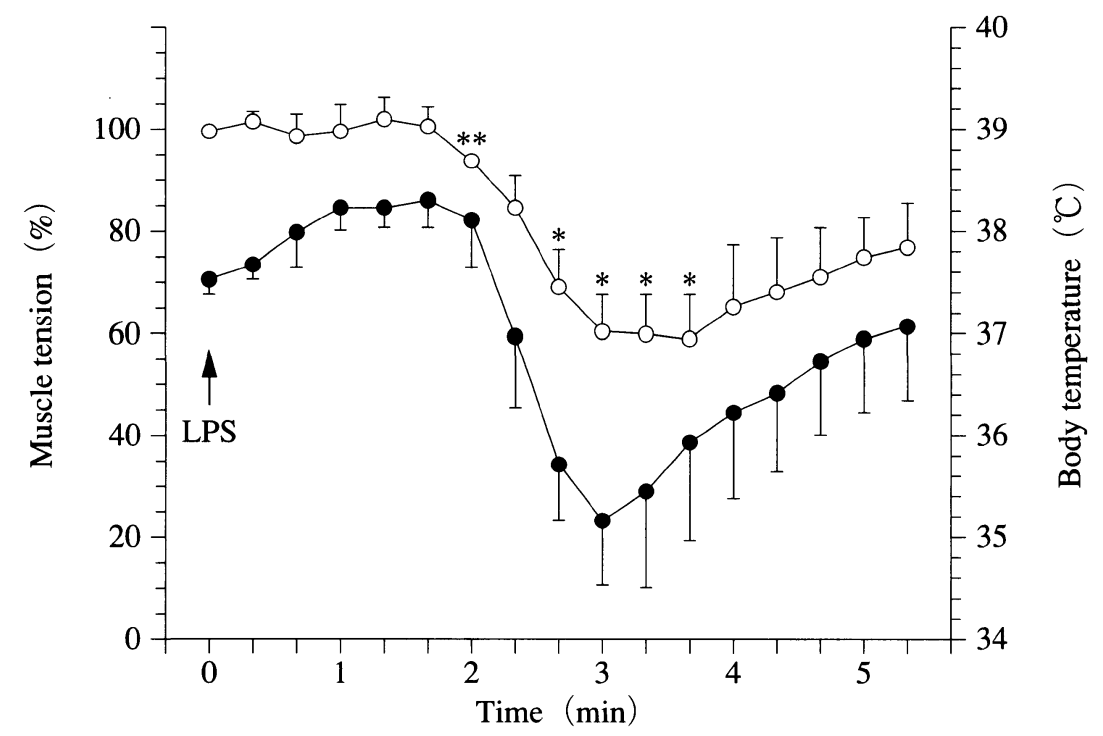

Fig. 6. Effects of LPS on muscle tension of taenia caecum and body temperature in guinea pigs. Individual guinea pigs were injected with LPS $0.3 \mathrm{mg} / \mathrm{kg}$ intraperitoneally at the 0 time point.

${ }^{*} \mathrm{p}<0.05,{ }^{* *} \mathrm{p}<0.01$ compared with the corresponding point for the $10 \mathrm{~min}$ before injection of LPS. Points show the mean \pm SEM $(n=3)$.

$\bigcirc$ - muscle tension; - body temperature

compression and adhesion against abdominal visceral organs.

Contractile movement of the taenia caecum was analyzed in terms of both contractility (Fig. 3) and tension (Fig. 4). Effects of LPS were evaluated for each of these two points. Our results clearly demonstrated that LPS showed a characteristic effect on tension of the longitudinal muscle of the taenia caecum; LPS induced a reversible decrease in the muscle tension that was sustained for many hours. In other words, LPS has a relaxing action on the smooth muscle. The time required for reaching a relaxation peak was almost constant at any dose of LPS, which is also characteristic to the relaxing effect of LPS. Amplitude of relaxation was found to depend on the dose of LPS, while contractility, the other motor index for the taenia caecum muscle, did not show any dose dependency. These results suggest that the relaxing action of LPS is a specific response, which would be helpful for elucidating pathophysiology of endotoxemia.

The characteristic relaxing response appearing three to four hours after LPS administration could reflect a biological response in acute inflammation caused by LPS. Recent reports have proposed a possible mechanism for LPS-induced response, in which LPS binds to LPS-binding protein (LBP) to trigger a series of biological responses $^{7,8)}$. The LPS/LBP complex then binds to mem- brane-bound CD-14 (mCD14) expressed on monocytes and macrophages to transmit the signal to Toll-like receptor 4/ MD-2 complex ${ }^{9,10)}$, which consequently release cytokines such as tumor necrosis factor- $\alpha$ (TNF- $\alpha$ ) and interleukin-1 $\beta$ (IL-1 $\beta$ ). Through these processes, various responses leading to organ dysfunction and endotoxin shock should be induced. However, the precise mechanism of biological responses induced by LPS is not known.

The previous data have shown that concentrations of TNF- $\alpha$ and IL-1 $\beta$ transiently increase one to three and two to five hours, respectively, after intravenous injection of LPS in humans ${ }^{11)}$. Furthermore, heme oxygenase-1 (HO-1), a putative stress protein, and the serum level of IL-6 have been demonstrated to increase significantly three hours after intraperitoneal injection of LPS in rats ${ }^{12}$.

The biological mechanism by which the dose-dependent relaxing response with a peak at three to four hours after LPS administration is induced in the longitudinal muscle of the taenia caecum remains unknown. However, it is possible that some chemical mediators released by LPS that relax the intestinal smooth muscle could lower body temperature simultaneously (Fig. 6). It has been reported that low doses of LPS induce hyperthermia while high doses cause hypothermia in mice ${ }^{13)}$. In this report by Leon et al. ${ }^{13)}$, hyperthermia caused by LPS is suggested 
to be accompanied by increase in the plasma level of IL10 , but effects of IL-10 on the intestinal smooth muscle is not noted. Since production of IL-10 is induced by prostaglandin $\mathrm{E}_{2}\left(\mathrm{PGE}_{2}\right)^{14)}$, which is thought to be an important mediator for pyrexia, involvement of $\mathrm{PGE}_{2}$ in the intestinal relaxation and hyperthermia caused by LPS should be clarified in future work.

Significant decrease in tension of the longitudinal muscle observed after nine hours of administration of high doses of LPS (Figs. 1 and 4) is considered to be an irreversible relaxing response (Fig. 5), which might represent symptoms of septic multiple organ dysfunction syndrome (septic MODS). Oxygen free radical has been suggested to be involved in this step of multiple organ dysfunction ${ }^{15}$. Although recovery from this septic MODS is thought to be difficult, the initial relaxing response of the taenia caecum muscle with a peak at three to four hours after LPS administration might be inhibited by any means, which could possibly avoid subsequent organ dysfunction. Thus, our method for measuring the intestinal tension in conscious guinea pigs using intestinal relaxation and hyperthermia as parameters provides a useful experimental model in seeking for a therapeutic method for endotoxemia.

\section{References}

1) Schwarz NT, Beer-Stolz D, Simmons RL, et al: Pathogenesis of paralytic ileus: intestinal manipulation opens a transient pathway between the intestinal lumen and the leukocytic infiltrate of the jejunal muscularis. Ann Surg 2002; 235: 31-40.

2) Sola R, Soriano G: Why do bacteria reach ascitic fluid? Eur J Gastroenterol Hepatol 2002; 14: 351-4.

3) Belyansky LS, Sayenko VF, Furmanov JA, et al: Bacterial translocation as a cause for septic complications in obstructive colonic ileus. Acta Chir Belg 2002; 102: 75-7.
4) Akin ML, Uluutku H, Erenoglu C, et al: Hyperbaric oxygen ameliorates bacterial translocation in rats with mechanical intestinal obstruction. Dis Colon Rectum 2002; 45: 967-72.

5) Ninomiya N, Nemoto K, Okamura $T$, et al: Suppression of guinea pig intestinal tract contraction by lipopolysaccharide. J Jap Associ Acute Medicine 2000; 11:651-9.

6) Nakajima M, Sakai T, Mizumoto A, et al: Development of a new telemetry recording system for measuring of gastrointestinal contractile activity in unrestrained and conscious small animals. J Smooth Muscle Res 1996; 32: 1-7.

7) Gegner JA, Ulevitch RJ, Tobias PS: Lipopolysaccharide (LPS) signal transduction and clearance. Dual roles for LPS binding protein and membrane CD14. J Biol Chem 1995; 270: 5320-5.

8) Schumann RR, Latz E: Lipopolysaccharide- binding protein. Chem Immunol 2000; 74: 42-60.

9) Chow JC, Young DW, Golenbock DT, et al: Toll-like receptor-4 mediates lipopolysaccharide-induced signal transduction. J Biol Chem 1999; 274: 10689-92.

10） Egil L, Robin RI: Toll-like receptors. Crit Care Med 2002; 30 (Suppl): S1-11.

11) Nakano M, Kodama $M$ :Endotoxemia. In: Endotoxin. Kodansya Ltd., Tokyo, 1995, p 189-90.

12) Takahashi T, Suzuki T, Yamasaki A, et al: Heat shock response in a rat model of septic multiple organ dysfunction syndrome. Nippon Yakurigaku Zasshi 1999; 114 : 295302.

13) Leon LR, Kozak W, Rudolph K, et al: An antipiretic role for interleukin-10 in LPS fever in mice. Am J Physiol 1999; 276: R81-9.

14) Strassmann G, Patil-Koota V, Finkelman F, et al: Evidence for the involvement of interleukin 10 in the differential deactivation of murine peritoneal macrophages by prostaglandin E2. J Exp Med 1994; 180:2365-70.

15) Hata $F$, Takeuchi $T$ : Inhibitory neuronal control of smooth muscle activity of the gastrointestinal tract. Nippon Yakurigaku Zasshi 1997; 109: 61-73. 


\section{原著論文}

\section{エンドトキシン誘発腸管麻瘏の新しい測定法}

二宮 宣文 ${ }^{1}$ 根本 香代 ${ }^{2}$ 岡村 忠夫 ${ }^{2}$ 鈴木 秀典 ${ }^{2}$

山本 保博 1

要旨 Lipopolysaccharide(LPS)はsepsisによる麻痺性イレウスの原因物質と考えられている。われわれは，モル モットがLPSに対して高い感受性を示し, 摘出結腸縦走筋標本の収縮がLPSによって抑制されることを既に報告 した。本研究では, 意識下に扔ける無拘束モルモットの結腸縦走筋運動変化を連続的に観察・記録し, LPS投与 による腸管麻痺の新しい測定法の開発を試みた。モルモットを麻酔下に開腹し, 結腸紐に極小のforce transducer を逢着した。術後のモルモットは飼育ケージ内で自由に飲水・摂食させ，4 日後にLPS（E. coli, O111:B4）を腹 腔内投与し, 結腸縦走筋運動をモニターした。また，背部皮膚に装着した温度計によりLPS投与後の体温変化を 経時的に測定した。モルモットの腸管収縮運動は, 長時間にわたり安定した記録が得られた。LPS 投与後2-4 時 間でピークを示す特徴的な結腸縦走筋の弛緩反応が認められた。LPS投与による弛緩反応は, LPS投与濃度に依 存していた。また, 体温は腸管の張力とよく相関する变化を示した。以上の結果から, 意識下無拘束モルモット の腸管運動の新しい測定法は, エンドトキシン投与による麻㿁性イレウスを研究するための有用な方法であるこ とが示唆された。

(日救急医会誌 $2003 ; 14: 241-50)$

キーワード: 敗血症, イレウス, lipopolysaccharide, 平滑筋, モルモット

${ }^{1}$ 日本医科大学救急医学 2 同薬理学 